\title{
Japanese government debt and sustainability of fiscal policy
}

\author{
Takero Doi $^{\mathrm{a}, \mathrm{b}}$, Takeo Hoshi ${ }^{\mathrm{b}, \mathrm{c}, \mathrm{d}, *}$, Tatsuyoshi Okimoto ${ }^{\mathrm{e}}$ \\ ${ }^{\text {a }}$ Faculty of Economics, Keio University, Japan \\ ${ }^{\mathrm{b}}$ TCER, Japan \\ ' School of International Relations and Pacific Studies, University of California, San Diego, United States \\ ${ }^{\mathrm{d}}$ NBER, United States \\ ${ }^{\mathrm{e}}$ Graduate School of International Corporate Strategy, Hitotsubashi University, Japan
}

\section{A R T I C L E I N F O}

\section{Article history:}

Available online 1 October 2011

\section{JEL classification:}

E6

H5

H6

\section{Keywords:}

Debt to GDP ratio

Minimum tax rate for fiscal sustainability

Markov switching model

Active policy

Passive policy

\section{A B S T R A C T}

Doi, Takero, Hoshi, Takeo, and Okimoto, Tatsuyoshi-Japanese government debt and sustainability of fiscal policy

We construct quarterly series of the revenues, expenditures, and debt outstanding for Japan from 1980 to 2010, and analyze the sustainability of the fiscal policy. We pursue three approaches to examine the sustainability. First, we calculate the minimum tax rate that stabilizes the debt to GDP ratio given the future government expenditures. Using 2010 as the base year, we find that the government revenue to GDP ratio must rise permanently to $40-$ $47 \%$ (from the current 33\%) to stabilize the debt to GDP ratio. Second, we estimate the response of the primary surplus when the debt to GDP ratio increases. We allow the relationship to fluctuate between two "regimes" using a Markov switching model. In both regimes, the primary surplus to GDP ratio fails to respond positively to debt, which suggests the process is explosive. Finally, we estimate a fiscal policy function and a monetary policy function with Markov switching. We find that the fiscal policy is "active" (the tax revenues do not rise when the debt increases) and the monetary policy is "passive" (the interest rate does not react to the inflation rate sufficiently) in both regimes. These results suggest that the current fiscal situation for the Japanese government is not sustainable. J. Japanese Int. Economies 25 (4) (2011) 414-433. Faculty of Economics, Keio University, Japan; TCER, Japan; School of International Relations and Pacific Studies, University of California, San Diego, United States; NBER, United States; Graduate School of International Corporate Strategy, Hitotsubashi University, Japan.

(c) 2011 Elsevier Inc. All rights reserved.

* Corresponding author at: School of International Relations and Pacific Studies, University of California, San Diego, United States. E-mail address: thoshi@ucsd.edu (T. Hoshi). 


\section{Introduction}

Mounting government debt is a serious issue in many countries in Europe, the US, and Japan. The concern on sustainability of increasing government debt already put Greece into a serious crisis, and other European countries had to bail out Greece twice already (May 2010 and July 2011) in concert with the IMF. Ireland (November 2010) and Portugal (April 2011) followed suit. Increasing debt and slow economic growth has increased the cost of financing for other troubled economies such as Spain and Italy. The fiscal problem for the US looked less pressing, but the political gridlock and the inability to come up with a credible plan to put the government finance in order drove the US dangerously close to default in August 2011. Although the worst case scenario of the outright default was avoided at the last minute, the US politicians still face a difficult task of building a consensus on how the burden of deficit reduction should be shared.

Japan also suffers from a serious problem of the government debt. Indeed Japan's problem seems more serious when we look at the (gross) debt to GDP ratio. The OECD figure for 2010 shows that Japan's debt to GDP ratio was $198 \%$, which is much higher than the US (93\%), the UK ( $81 \%)$, France (92\%), Germany (80\%), and even Greece (129\%).

Japan's debt is a result of continued deficits of many more years than the US or Europe. The start of the increasing government debt goes back to the fiscal stimulus packages in the early 1990s, when the Japanese economy suffered from the collapse of asset prices. There have been a couple of attempts of fiscal consolidation, but neither of them lasted long enough to achieve the initial goals, and the debt has continued to increase.

This paper examines the sustainability of Japan's fiscal policy. There are two contributions that the paper makes to the discussion of fiscal sustainability for Japan. First, the paper presents reliable quarterly data for the budget deficit and the government debt of Japan from 1980 to 2009. The data are comprehensive in that the coverage includes both central and local governments and almost all the government accounts including the social security fund. We also create the data series for only the central/local governments, excluding the social security account.

Second, the paper takes three complementary approaches to examine the sustainability. The first approach is that of Broda and Weinstein (2005) and Doi (2009). Here the question is how much the government needs to raise the tax revenue to stabilize the debt to income ratio in the long run given the future government expenditures and transfers. The second approach is an extension of Bohn (1998), and considers the dynamic feedback from the level of government debt to future government surpluses. The third approach considers the responses of tax revenues to the level of debt as well as the fluctuations in the government expenditures, following Davig and Leeper (2007).

The paper is organized as follows. In the next section, we briefly trace the evolution of the Japan's government debt over the last 20 years. Section 3 explains how we construct the quarterly data series of budget deficit and government debt that we use for the empirical analysis. In Section 4, we update the analyses of Broda and Weinstein (2005) and Doi (2009), and calculate the minimum tax rate that Japan needs to stabilize the debt to GDP ratio. Section 5 estimates a feedback rule from the level of government debt to the primary surplus to see if we observe stabilizing response of fiscal surpluses as the government debt increases in Japan. We extend the analysis of Bohn (1998) by considering the possibility that such a feedback rule has fluctuated between two different regimes over time. Section 6 estimates the fiscal policy function that models the tax revenues as a function of the government debt, output gap, and the government expenditure. The model allows two regimes with different responses of the government revenues. We also estimate a monetary policy function that is also state contingent, and discuss the interactions between the fiscal policy regimes and the monetary policy regimes. Section 7 concludes.

\section{Accumulation of government debt in Japan: 1991-2010}

In the fiscal year 1990, the Japanese government believed that it had succeeded in containing the budget deficit problem that plagued them since the late 1970s, but it did not last long. To fight 


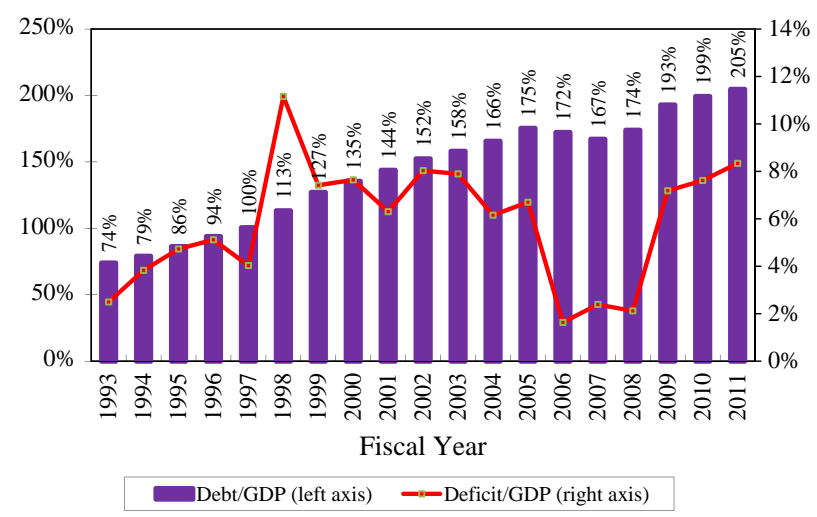

Fig. 1. Budget deficit and government debt: fiscal 1993-2011. Source: OECD Economic Outlook 87 database. Annex Table 27.

the recession following the collapse of asset price boom, the government turned to a series of fiscal stimulus during the first half of 1990s. ${ }^{1}$ Fig. 1 shows the deficit to GDP ratio and the debt to GDP ratio for the 1990s and the 2000s. The numbers are for the government sector as a whole, which includes the central as well as local governments and the social security funds. The numbers for 2010 and 2011 are for the initial budgets.

The figure shows that the government continued to run budget deficit throughout the last two decades. There have been some episodes when the budget deficit declined in proportion to GDP when the economy recovered and/or the government tried to reduce the deficits (1996, 2000, 2005-2007). The deficit to GDP ratio, however, increased from $2.5 \%$ in 1993 to about $8 \%$ by the end of the 1990 s and most of the 2000s. Reflecting this trend in the deficits, the debt to GDP ratio steadily increased from $74 \%$ to $200 \%$ by the end of 2000 s.

Although the governments of many developed economies now face the fiscal problem, the Japan's problem looks extremely serious. For example, from 1997 to 2005, one finds that Japan's budget deficit to GDP ratio was the largest among G7 countries. From 1999 on, Japan has the highest debt to GDP ratio among G7 countries. The ratio exceeded $200 \%$ after 2010. In terms of net debt, which subtracts the financial assets that the government sector owns from the gross debt, Japan looks slightly better. The Japanese government sector owns substantial financial assets (most notably in the social security funds), some of which are invested in the Japanese government bonds. For example, as of March 2009, the social security funds (reserves for government-run pension systems) had the net financial assets of about 200 trillion yen (about 40\% of GDP). Even with this measure, however, the Japan's debt to GDP ratio has been the highest among G7 since 2008. The net debt to GDP ratio stood around $120 \%$ for Japan in 2010.

The Japanese government debt has been rising very rapidly. It is obvious that the debt to GDP ratio cannot continue growing forever. At one point, the debt to GDP ratio must be stabilized (unless the Japanese government declares defaults). What are the conditions to stabilize the debt to GDP ratio at a certain level in the future? How much longer would the debt to GDP ratio continue rising before it starts to decline? How is such a policy change likely to happen in Japan given its past fiscal policy regimes? These are the questions that we ask in this paper.

\section{Data construction}

The fiscal data used in the econometric analysis in Sections 5 and 6 are constructed from the national income accounting published by the Cabinet Office of the Japanese government. We create quarterly time series from the first quarter of 1980 to the first quarter of 2010 for government

${ }^{1}$ Doi and Ihori (2009, pp. 24-31) summarizes major developments of Japanese fiscal policy from 1981 to 2007. 
expenditure, revenue, primary deficit, and debt for two alternative definitions of the government sector: the central/local governments and the general government sector that also includes the social security funds. The data set is available for download at http://web.econ.keio.ac.jp/staff/tdoi/ DHOdata.html.

The total expenditure and revenue series for the general government are readily available in the national income accounting at quarterly frequency with a couple of exceptions. For the capital transfers and net purchases of land, the data are available only at annual frequency. We can use, however, two types of annual series: calendar years and fiscal years. For the initial year (1980), we create the quarterly numbers by dividing the amount for the calendar year by four. Then, we calculate the first quarter number for the second year by subtracting the sum of the last three quarters of the first year from the fiscal year number for the first year. Subtracting the first quarter number from the calendar year number for the second year, we can calculate the number for the last three quarters. Iterating this process, we can estimate the first quarter number and the total of the last three quarters for every year. Finally, the number for the last three quarters each year is divided into individual quarterly numbers, taking into account the trend increase observed in the first quarter numbers. ${ }^{2}$

The revenues and expenditures by subsector are available only annually, so we construct the quarterly data in the following way. For most items, we first estimate the quarterly amount for the social security funds sector, and the numbers for the central/local governments sector are obtained by subtracting the numbers for the social security account. The exceptions are transfers within the general government sector. For those series, data on the central/local governments side are publicly available, so we calculate the quarterly amount for the central/local governments first and then subtract the number from the general government sector number to obtain the amount for the social security sector. Table 1 shows how each relevant item in the national income accounts is estimated for each subsector.

Some expenditure or revenue items apply only to the central and local governments. For example, many tax revenue items, including income tax revenue and value added tax revenue, accrue only to the central and local governments. For those items, we can safely assume the amount for the social security funds is always zero. Some other items such as social security contributions apply only to the social security funds. For those items, we just take the quarterly amount for the entire general government sector as the amount for the social security funds. For the other items, we estimate the quarterly amounts for social security account by prorating the annual numbers. The expenditures and revenues related to financial transactions other than the interest payment, such as dividends received, rents paid and purchases of land, are estimated by dividing the annual amounts by four. The other items including the interest payment, the final consumption, the fixed capital formation, the current transfers are calculated so that the proportion of the social security account (in the general government sector) at each quarter is the same as the proportion of annual flows for the fiscal year.

For the transfers within the general government sector, we first use Ministry of Finance "Financial Statistics Monthly" and Ministry of Internal Affairs and Communications "White Paper on Local Public Finance" to estimate the amount for the local/central governments sector. Then, we calculate the number for the social security sector by subtracting the number for the local/central government sector from the number for the general government sector.

\footnotetext{
${ }^{2}$ Let $Y_{t}$ be the amount for the fiscal year $t$ and $X_{i t}$ be the estimated amount for the ith quarter of year $t$; i.e., $Y_{t}=X_{2 t}+$ $X_{3 t}+X_{4 t}+X_{1++1}$. We estimate the amounts for the second, third, and fourth quarter of each year from the total amount for the calendar year and the first quarter amount using the following formulas.
}

$$
\begin{aligned}
& X_{2 t}=\left(Y_{t}-X_{1 t+1}\right) \frac{3 X_{1 t}+X_{1 t+1}}{6\left(X_{1 t}+X_{1 t+1}\right)} \\
& X_{3 t}=\left(Y_{t}-X_{1 t+1}\right) \frac{2 X_{1 t}+2 X_{1 t+1}}{6\left(X_{1 t}+X_{1 t+1}\right)}=\frac{Y_{t}-X_{1 t+1}}{3} \\
& X_{4 t}=\left(Y_{t}-X_{1 t+1}\right) \frac{X_{1 t}+3 X_{1 t+1}}{6\left(X_{1 t}+X_{1 t+1}\right)}
\end{aligned}
$$


Table 1

Calculation of quarterly data by sub-sector.

\begin{tabular}{clc}
\hline Transactions & $\begin{array}{l}\text { Central and local } \\
\text { governments }\end{array}$ \\
\hline
\end{tabular}

Income and outlay accounts

1. Taxes on production and imports, receivable
(1) Taxes on products
a. Value added type taxes (VAT)
b. Import duties
c. Others
(2) Other taxes on production

2. (less) Subsidies, payable

3. Property income, receivable
(1) Interest
(2) Distributed income of corporations
a. Dividends
b. Withdrawals from income of quasi-corporations
(3) Property income attributed to insurance policy holders
(4) Rent

5. Property income, payable
(1) Interest
(2) Rent

8. Current taxes on income, wealth, etc., receivable
(1) Taxes on income
(2) Other current taxes
9. Social contributions, receivable
(1) Actual social contributions
a. Compulsory employers' actual social contributions
b. Compulsory employees' social contributions
(2) Imputed social contributions

$\begin{array}{ll}\text { I } & 0 \\ \text { I } & 0 \\ \text { I } & 0 \\ \text { I } & 0 \\ \text { I } & 0\end{array}$

$\begin{array}{ll}\text { IV } & \text { II } \\ \text { I } & 0 \\ \text { IV } & \text { III } \\ \text { I } & 0 \\ \text { IV } & \text { III }\end{array}$

10. Other current transfers, receivable
(1) Non-life insurance claims
(2) Current transfers within general government
a. From central government
b. From local government
c. From social security funds
(3) Current international cooperation
(4) Miscellaneous current transfers

IV

I

I 0

12. Social benefits other than social transfers in kind, payable

(1) Social security benefits in cash

(2) Unfunded employee social benefits

(3) Social assistance benefits

$\begin{array}{ll}0 & \text { I } \\ 0 & \text { I } \\ \text { Same as 12(2) by } & \begin{array}{l}\text { Same as 12(2) by } \\ \text { definition }\end{array}\end{array}$

13. Other current transfers, payable

(1) Net non-life insurance premiums

(2) Current transfers within general government
a. To central government
b. To local government
c. To social security funds

(3) Current international cooperation

(4) Miscellaneous current transfers

17. Final consumption expenditure

$\begin{array}{ll}\text { IV } & \text { II } \\ \text { V } & \text { IV } \\ \text { V } & \text { IV } \\ \text { V } & \mathrm{N} / \\ \text { I } & 0 \\ \text { IV } & \text { II }\end{array}$

Capital finance accounts

19. Capital transfers, receivable

(1) From other sub-sectors of general government

(2) From residents

a. Of which capital taxes

b. Of which special factors

0

IV

I

IV

Same as 10(2)b

Same as 10(2)a

Same as 10(2)a and b

I

IV

IV

IV

IV

$\mathrm{N} / \mathrm{A}$

II

I
II
0

Same as $10(2)$

Same as $10(2)$

I

0
A part of 10 (2)c

A part of $10(2) \mathrm{C}$

N/A

0

II

II

0
0
0
0

II
0
III
III

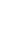

0 
Table 1 (continued)

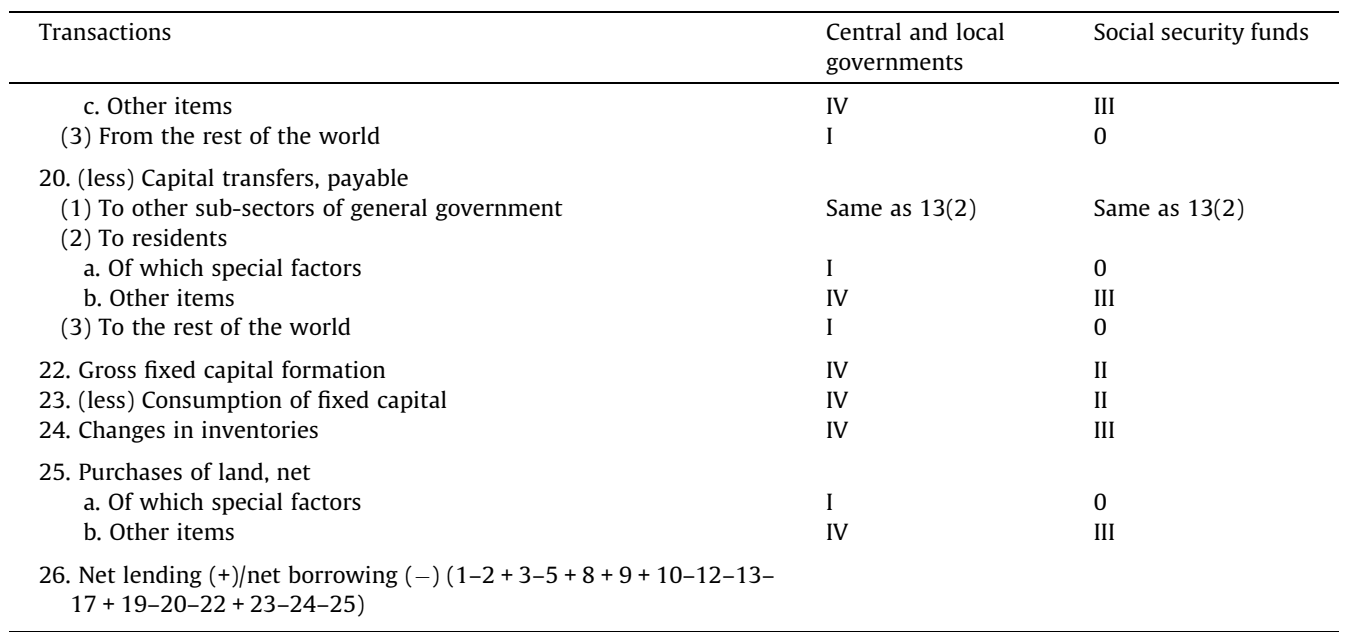

Notes: The item numbers correspond to those used by the official reports of national income accounting. The letter in each cell shows how the item for the subsector is estimated.

0 . The amount is zero.

I. Same as the amount for the entire general government.

I'. Same as the amount for the entire general government if the special factor for the quarter applies to the subsector.

II. Calculated so that the proportion of the social security account in each quarter is the same as the proportion of annual amounts for the year.

III. Calculated by dividing the annual amounts by four.

IV. Subtracting the amount for the social security account from the amount for the whole general government sector.

V. Estimated from the Ministry of Finance "Receipts and Payments of Treasury Funds with the Private Sector" and the Ministry of Internal Affairs and Communications "White Paper on Local Public Finance" is adopted.

We also adjust for temporary fluctuations caused by known unusual events that happened in each account. ${ }^{3}$ Such special transfers between public corporation and the government are excluded from government expenditures and revenues series.

The debt outstanding series in the national income accounting is available only in annual frequency, too. Again we estimate the quarterly series using both calendar year series and fiscal year series. Since the debt outstanding is a stock data, the amount at the end of the fourth quarter is the same as the amount at the end of the calendar year, and the amount at the end of the first quarter is the same as the amount at the end of the previous fiscal year. For the periods before 1998, we estimate the second quarter and third quarter numbers by linearly interpolating the series. For the periods after 1998, we use the Bank of Japan Flow of Funds data to match the seasonal pattern of the debt outstanding series for each sector to the seasonal pattern of the corresponding data in the flow of funds statistics. ${ }^{4}$

\footnotetext{
${ }^{3}$ These include transfers of liabilities from the Japanese National Railways Settlement Corporation and the Special Account for National Forest Service to the general account of the central government in 1998, returns of the public part of pension reserves from employee pension funds to the Welfare Insurances Special Account of the central government (so-called daikō henjō) for years from 2003 onward, transfers of assets and liabilities from the former Japan Highway Public Corporation and other three highwayrelated public corporations to the Japan Expressway Holding and Debt Repayment Agency, which took place in the privatization of these public corporations in 2005, transfers of funds from the Special Account for Fiscal Loan Program Funds to the Special Account for Government Bonds Consolidation Fund, which are based on the special law on issues of government bonds in 2006, transfers of funds from the Special Account for Fiscal Investment and Loan Program to the Special Account for Government Bonds Consolidation Fund and the General Account, which are based on the act on Special Accounts, and the special law on the issues of transfers of funds from the Special Account for Fiscal Investment and Loan Program in 2008.

${ }^{4}$ The BOJ Flow of Funds data for debt outstanding by subsector are not available for periods before the fourth quarter of 1997. The numbers reported in the System of National Accounting (SNA) and those in the flow of funds statistics, however, do not match, perhaps reflecting different treatments of capital gains.
} 
We construct the budget surplus (called net lending/net borrowing in the official SNA statistics) and primary surplus at quarterly frequency from the revenues and expenditures series. The budget surplus (or deficit) number is generally not equal to the increase in the net government asset (or debt), because the latter includes the capital gains (and losses) and other changes in the value of government assets and liabilities. So we define reconciliation term as follows:

Net debt at the end of this year = net debt at the end of previous year

- "net lending/net borrowing" + special factor term

+ reconciliation term

As the measure of debt for our analysis, we used the "adjusted net debt" proposed by Doi (2008), which is defined as the gross debt of the government sector minus the financial assets owned by the government sector that are readily disposable. This differs from the standard definition of the net debt in that some financial assets at the central and local governments such as the fiscal adjustment funds of the local governments are not subtracted from the gross debt. These financial assets are held as a buffer for unexpected losses and not expected to be drawn down to redeem the debt.

\section{Minimum tax rate for sustainable fiscal policy}

This section calculates the minimum amount of taxes (in proportion to GDP) that makes the fiscal policy sustainable at a certain future date, given the future paths for government expenditures, following the method used by Broda and Weinstein (2005) and Doi $(2008,2009)$. This approach defines the sustainable fiscal policy to be the one that stabilize the debt to GDP ratio at the level in the base year, as proposed in Blanchard et al. (1990). We start from a basic inter-temporal budget constraint for the government:

$$
B_{t}-B_{t-1}=G_{t}-T_{t}+i B_{t-1}
$$

where $B_{t}$ stands for the amount of government debt outstanding at the end of period $t, G_{t}$ and $T_{t}$ are the government expenditure (including transfers) and the tax revenues respectively during the period $t$, and $i$ is the interest rate that is assumed to be constant. ${ }^{5}$ All variables are in real terms. Dividing the both side of the equation by GDP for the period $t, Y_{t}$, and rearranging it, we get:

$$
\begin{aligned}
& \frac{B_{t}}{Y_{t}}=\frac{G_{t}-T_{t}}{Y_{t}}+\frac{1+i}{1+\eta} \frac{B_{t-1}}{Y_{t-1}} \text { or } \\
& b_{t}=g_{t}-\tau_{t}+\frac{1+i}{1+\eta} b_{t-1}
\end{aligned}
$$

where $b_{t}, g_{t}$, and $\tau_{t}$ denote the government debt, the government expenditure, and the tax revenues respectively divided by GDP, and $\eta$ is the growth rate of GDP, which is also assumed to be constant. We assume $i \geqslant \eta$. If the long-run growth rate of GDP exceeded the long-run interest rate, sustainability of fiscal policy would not be an issue.

Rearranging the terms, we can express the debt to GDP ratio as a function of the future debt to GDP ratio and the future primary surplus:

$$
b_{t-1}=\frac{1+\eta}{1+i} b_{t}+\frac{1+\eta}{1+i}\left(\tau_{t}-g_{t}\right)
$$

\footnotetext{
${ }^{5}$ In reality, both the growth rate and the interest rate fluctuate over time. The constant rates assumed here should be interpreted as the long run averages that matters for the debt dynamics in a long horizon, such as 100 years. Thus, our aim is not to predict the path of the debt to GDP ratio in the next few years or in the next few decades. Hence we ignore the possibility of zero interest rate, assuming what we have observed in Japan for the last couple of decades and in other advanced economies in the late 2000 s is an abnormal situation and the interest rate cannot stay at zero in the long run. What we also ignore here is the possibility that the interest rate starts to increase as the debt to GDP ratio rises. Such an extension would make it even tougher for the government to stabilize the debt to GDP ratio once it starts increasing.
} 
Solving the equation forward, we get:

$$
b_{0}=\left(\frac{1+\eta}{1+i}\right)^{n} b_{n}+\sum_{t=1}^{n}\left(\frac{1+\eta}{1+i}\right)^{t}\left(\tau_{t}-g_{t}\right)
$$

The current debt to GDP ratio must be equal to the present discount value of the future debt to GDP ratio and the series of future primary surpluses.

The sustainability requires that the debt to GDP ratio at some distant future $n$ comes back to the level at the period zero. We can calculate the constant tax rate $\tau^{*}$ that makes $b_{0}=b_{n}$ to be:

$$
\tau^{*}=\left\{\begin{array}{l}
\frac{i-\eta}{1+\eta}\left[b_{0}+\left\{1-\left(\frac{1+\eta}{1+i}\right)^{n}\right\}^{-1} \sum_{t=1}^{n}\left(\frac{1+\eta}{1+i}\right)^{t} g_{t}\right] \text { if } i>\eta \\
\frac{1}{n} \sum_{t=1}^{n} g_{t} \quad \text { if } i=\eta
\end{array}\right.
$$

Taking the fiscal year 2003 as the base year, Broda and Weinstein (2005) find that the Japan needs to raise the tax revenues to around 35\% of GDP if the government expenditure is to grow at the rate of GDP, and to around 40\% of GDP if the government expenditure is to grow at the rate of GDP per workers, in order to stabilize the net debt to GDP ratio. These numbers were compared to the tax rate of around 27\%, the actual number for Japan in 2003 (including the social security contributions). The numbers required for sustainability are high but not extremely high, compared with the tax rates in other advanced economies. This calculation led Broda and Weinstein (2005) to conclude that the fiscal situation in Japan is not as dire as some observers claimed.

It is important to note, however, that the Japanese government debt increased further since the time they did this calculation. Doi (2009) performed a similar calculation using fiscal 2008 as the base year. He finds that the tax rate that makes the fiscal policy sustainable tends to be higher than those estimated by Broda and Weinstein. For example, if the government expenditure grows at the rate of GDP, the necessary tax rate is about $40 \%$ even under the scenarios with less generous government transfers.

In Doi (2009), a new population projection in December 2006 presented by the National Institute of Population and Social Security Research is used (Broda and Weinstein (2005) use the 2002 projection). In the 2006 projection, the fertility rate forecast for 2050 was lowered to about 1.2 from the 2002 projection value of 1.39 . The revision reflects a growing tendency among Japanese women to get married and give birth later in life and increasing divorce rate. According to the latest census data, the country's population peaked in 2004 at 127.790 million. The population fell by 22,000 in 2005 .

After the publication of Broda and Weinstein (2005), newer sets of estimates of some future government expenditures became available. Thus, Doi (2009) used those, rather than assuming the expenditures grows at the rate of GDP (or GDP per worker) for those expenditures and transfers.

For the public expenditures on medical and long term care, the 2008 estimates published by the National Congress on Social Security known as the "simulation" were used. Because the study disclosed the detailed inputs for the simulation (unusually transparent for a study done by a Japanese government organization), one could tweak the numbers as one sees fit. The cost on medical and long term care reported in the "simulation" includes the co-pay of the people who receive the service. To conform to the national income accounting framework, the future estimates of co-pay burdens are subtracted from the projected costs to obtain the future stream of medical and long term care burdens for the public sector.

The "simulation" considers several alternative scenarios for the future reforms of the national healthcare and long term care system. Scenario A assumes that the current system will continue without any reforms. Scenario B assumes some reforms to address rapidly increasing demand for healthcare and long-term care, and includes some sub-scenarios with different levels of generosity of the reform. In this paper, we focus on Scenario B1 with the least generous benefits stream and Scenario B3 which is the most generous.

For the public pension related expenditures, the 2009 pension prediction released by the MHLW in February 2009 is used. The prediction provides the forecasts for the future social security expenditures every 5 years. The basic inputs for the simulation are carefully documented and published, so one can 
modify those to fit the purposes of the analysis. Both the "simulation" and the pension prediction report different forecasts based on different macroeconomic assumptions. We take the baseline case, which assumes the nominal growth rate of $2.0 \%$, the nominal rate of return of the pension system of $4.1 \%$, and the inflation rate of $1.0 \%$.

The government expenditure items other than healthcare, long-term care and pension related ones are assumed to increase at the growth rate of GDP per worker.

In this section, we extend the analysis of Doi (2009) using 2010 as the base year. The initial adjusted net government debt to GDP ratio is $152.8 \%$. In Doi (2009), the adjusted net government debt to GDP ratio at the end of 2010 is estimated to be $144.0 \%$. Thus, the deficit situation has worsened again.

We consider three different cases, which differ in the scenario for the healthcare and long-term care reform. Case 1 assumes no reforms (Scenario A). Cases 2 and 3 assume the least generous reform (Scenario B1) and the most generous reform (Scenario B3) respectively. Fig. 2 shows the forecasts for the future government expenditures for each case. The ratio of the government expenditures to GDP never exceeds $40 \%$ in every case. This shows that the government projections for social security benefits and healthcare and long-term care expenses imply that those expenditures will be somehow contained even without additional reforms for healthcare and long-term care.

Table 2 shows the tax rate $\left(\tau^{*}\right)$ that is necessary to reduce the debt to GDP ratio in 2048 or 2105 back to the level of 2010. The calculation is based on the Eq. (6). For the length of horizon ( $n$ ), we consider two cases: 95 years and 38 years. The 95 years horizon is roughly the same as the longer horizon considered by Broda and Weinstein (2005) (98 years) and the horizon considered by Doi (2009) (90 years). The 38 years horizon is exactly the same as the shorter horizon considered by Broda and Weinstein (2005). Panel A reports the results for the 95 years horizon and Panel B reports the results for the 38 years horizon.

Case 1

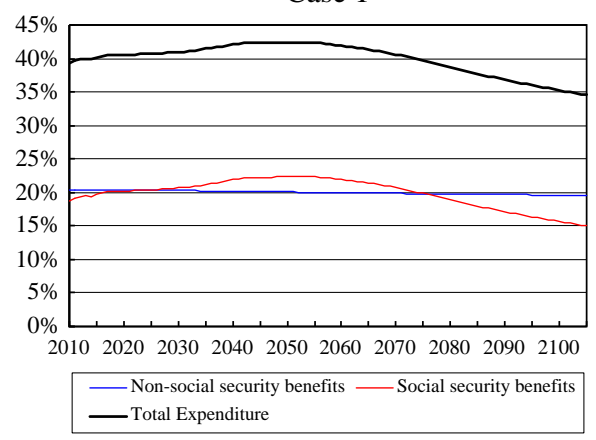

Case 2

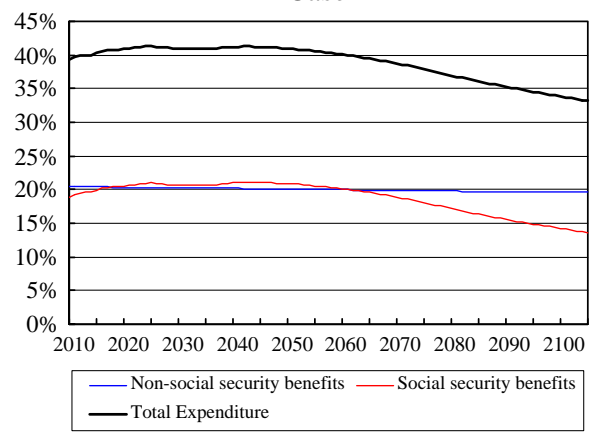

Case 3

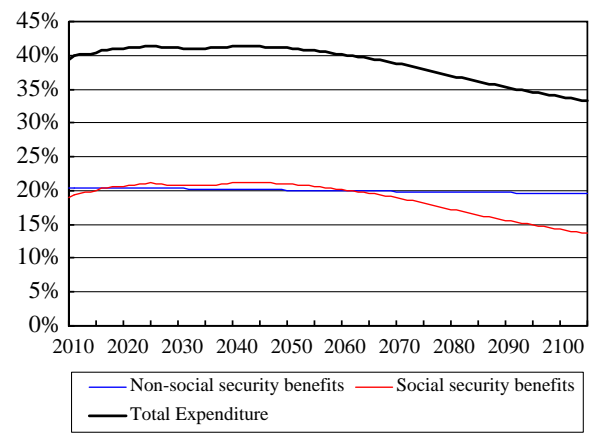

Fig. 2. Future government expenditures. 
Table 2

Simulation results of government revenue-GDP ratio required for fiscal sustainability.

\begin{tabular}{|c|c|c|c|c|c|c|}
\hline \multirow[t]{2}{*}{ Rate gap (interest rate) } & \multirow[t]{2}{*}{ Case 1} & \multirow[t]{2}{*}{ Case 2} & \multirow[t]{2}{*}{ Case 3} & \multicolumn{2}{|c|}{ Broda and Weinstein (2005) } & \multirow[t]{2}{*}{ Doi (2009) } \\
\hline & & & & Case 2 & Case 3 & \\
\hline \multicolumn{7}{|c|}{ Panel A. 95 years horizon, $\eta$ (nominal growth rate) $=2 \%$} \\
\hline $0 \%(2 \%)$ & $39.9 \%$ & $38.8 \%$ & $38.9 \%$ & $32.3 \%$ & $44.9 \%$ & $37.2 \%$ \\
\hline $1 \%(3 \%)$ & $41.8 \%$ & $40.9 \%$ & $41.0 \%$ & $33.7 \%$ & $44.4 \%$ & $38.8 \%$ \\
\hline $2 \%(4 \%)$ & $44.1 \%$ & $43.4 \%$ & $43.5 \%$ & $34.9 \%$ & $43.9 \%$ & $40.8 \%$ \\
\hline $3 \%(5 \%)$ & $45.2 \%$ & $44.6 \%$ & $44.7 \%$ & $36.0 \%$ & $43.3 \%$ & $41.7 \%$ \\
\hline $4 \%(6 \%)$ & $46.7 \%$ & $46.4 \%$ & $46.5 \%$ & $36.9 \%$ & $42.9 \%$ & $43.1 \%$ \\
\hline$n$ & 95 & 95 & 95 & 98 & 98 & 90 \\
\hline \multicolumn{7}{|c|}{ Panel B: 38 years horizon, $\eta$ (nominal growth rate) $=2 \%$} \\
\hline $0 \%(2 \%)$ & $41.1 \%$ & $40.9 \%$ & $41.0 \%$ & $35.3 \%$ & $40.2 \%$ & \\
\hline $1 \%(3 \%)$ & $42.5 \%$ & $42.4 \%$ & $42.5 \%$ & $35.9 \%$ & $40.4 \%$ & \\
\hline $2 \%(4 \%)$ & $44.7 \%$ & $44.6 \%$ & $44.7 \%$ & $36.5 \%$ & $40.6 \%$ & \\
\hline $3 \%(5 \%)$ & $45.4 \%$ & $45.3 \%$ & $45.4 \%$ & $37.0 \%$ & $40.8 \%$ & \\
\hline $4 \%(6 \%)$ & $46.8 \%$ & $46.8 \%$ & $46.9 \%$ & $37.6 \%$ & $41.0 \%$ & \\
\hline$n$ & 38 & 38 & 38 & 38 & 38 & \\
\hline
\end{tabular}

Panel A shows that the tax rates that are necessary to stabilize the debt to GDP ratio in about 100 years are higher than those in Broda and Weinstein (2005) or Doi (2009) for similar assumptions on the growth rate and the interest rate. For example, if we assume the interest rate is higher than the growth rate by $2 \%$ and no further reform on the national healthcare and long-term care systems (Case 1 ), the tax revenue to GDP ratio must be raised to $44.1 \%$ immediately to achieve the sustainability. The ratio of the government revenues to GDP is forecasted to be $32.9 \%$ for 2010 (OECD Economic Outlook). Thus, our calculation suggests that the government increase the revenues by more than $11 \%$ of GDP through tax increases and increases in social security contributions by taxpayers. Panel B shows that the sustainable tax rates for the 38 years horizon in our Cases 1,2, and 3 are only slightly higher than those for the 95 years horizon. This suggests that taking a longer horizon and spreading the cost over many generations would not reduce the tax burden of each generation very much. ${ }^{6}$

Fig. 3 shows the path of the primary balance for each case. The figure shows that the primary balance of $2-4 \%$ of GDP has to be maintained for years. The primary balance reaches close to $10 \%$ of GDP toward the end. Even in the booming 1980s, Japan did not experience primary surplus continuing for a decade. Although such magnitude of primary surplus is possible, it is hard to imagine that voters would accept such sustained fiscal austerity without resistance.

Even with the extremely high tax rates, the debt to GDP ratio is forecasted to rise substantially before it starts to come down. Fig. 4 shows the implied path for the adjusted net debt to GDP ratio for each case. In all the cases that we consider, the debt to GDP ratio goes higher than $200 \%$ before it comes down. Noting that the total financial assets of the household sector currently amount to about $300 \%$ of GDP, the government may face substantial trouble refinancing the debt somewhere along this path.

To make the situation worse, the Great East Japan Earthquake struck on March 11, 2011. A large amount of additional government expenditure will be necessary for reconstruction of the affected areas. The cost for rebuilding the lost infrastructures is estimated to be around 16-25 trillion yen

\footnotetext{
${ }^{6}$ We also tried the calculation with simpler assumptions about the future government expenditures and transfers following Broda and Weinstein (2005). We considered their Case 2 where the government expenditure and transfer per person are expected to grow at the rate of GDP and their Case 3 where the government expenditure and transfer per person are expected to grow at the rate of GDP per worker. It turns out these scenarios provide more extreme versions of the future government expenditures and transfers than the scenarios that we consider. In their Case 2, the government expenditures to GDP ratio eventually start to decline more rapidly than any of our cases. In their Case 3, the government expenditures to GDP ratio continues to grow indefinitely. In either case, the qualitative result does not change. The tax rate that achieves sustainability is higher than that calculated by Broda and Weinstein (2005). For their Case 3, for example, a tax rate higher than 55\% is necessary to stabilize the debt to GDP ratio in 95 years.
} 


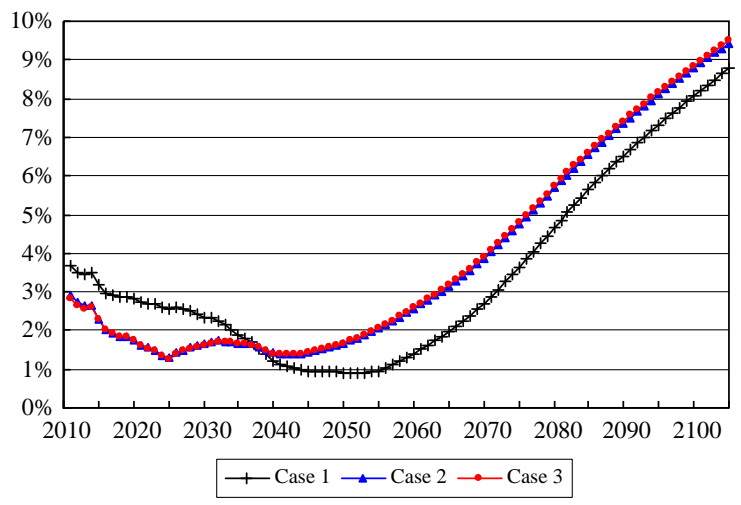

Fig. 3. Primary surplus under each scenario (with tax increases to $\tau^{*}$ ).

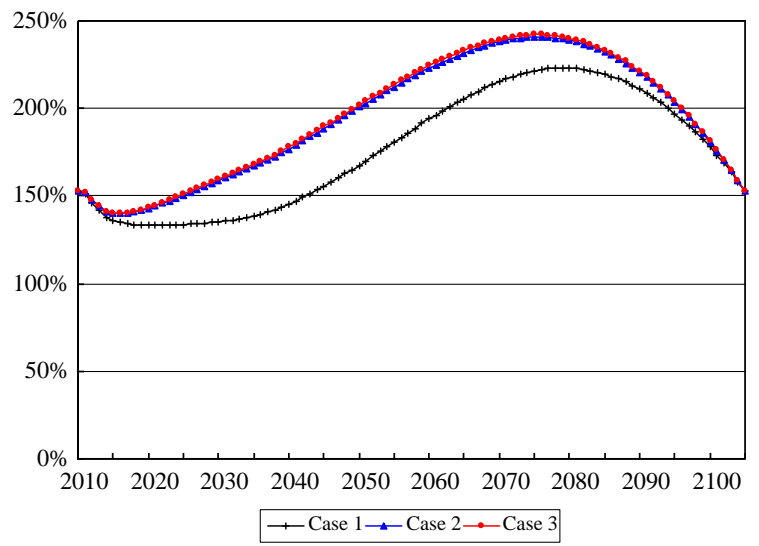

Fig. 4. Adjusted net debt to GDP ratio under each scenario.

(about 200 or 300 billion dollars at the exchange rate of 80 yen per dollar) by the Japanese government. According to the Basic Principles for Reconstruction that the government agreed on July 29, 2011, the government will spend 19 trillion yen in the 5 years (about $\$ 240$ billion or about $4.1 \%$ of GDP in 2010).

How has the disaster and additional expenditures on the recovery efforts changed the fiscal sustainability? For simplicity, let us consider the case when the government immediately pays for the total reconstruction expenditure by issuing new bonds. This is the case when the reconstruction expenditure has the maximum impact for the sustainability calculation.

Following steps similar to the derivation above, one can show that the minimum tax rate for sustainability $\tau^{*}$ is given by:

$$
\tau^{*}=\left\{\begin{array}{l}
\frac{i-\eta}{1+\eta}\left[b_{0}+\left\{1-\left(\frac{1+\eta}{1+i}\right)^{n}\right\}^{-1}\left\{d_{0}+\sum_{t=1}^{n}\left(\frac{1+\eta}{1+i}\right)^{t} g_{t}\right\}\right] \quad \text { if } i>\eta \\
\frac{1}{n}\left\{d_{0}+\sum_{t=1}^{n} g_{t}\right\} \quad \text { if } i=\eta
\end{array}\right.
$$

where $d_{0}$ denotes the ratio of the reconstruction expenditure to GDP. Comparing this to the Eq. (6), we see that the sustainable tax rate increases by 


$$
\frac{i-\eta}{1+\eta}\left\{1-\left(\frac{1+\eta}{1+i}\right)^{n}\right\}^{-1} d_{0} \quad \text { if } i>\eta \quad \text { or } \frac{1}{n} d_{0} \quad \text { if } i=\eta
$$

Substituting $d_{0}$ with $4.1 \%$ (the amount of reconstruction spending in the next 5 years according to the Basic Principles for Reconstruction), we see the increase in the sustainable tax rate is limited to 0.05$0.20 \%$ points in the 95 years horizon case. Thus, although the reconstruction cost may be substantial, its impact on the sustainability calculation is minimal because the cost can be spread over the long horizon.

We can use the Eq. (8) to examine the impact of a one-time reduction of the outstanding debt through outright default or instantaneous inflation. For example, if we consider an extreme case where the value of current debt is cut by half $\left(d_{0}=-76.4 \%\right)$, the sustainable tax rate falls by $0.8-$ $3.1 \%$ points in the 95 years horizon case. The numbers are larger (in absolute term) than the impacts of the reconstruction expenditure, but does not change the fiscal sustainability problem very much. Japan would still need large amount of tax increase to stabilize the debt. This suggests that the problem for Japan mostly comes from the future government expenditures and transfers that are expected to far exceed the future tax revenues. Although the current level of debt looks enormous, that is only a small part of the much bigger problem. Thus, the reduction of the value of just current debt outstanding does not solve the problem by itself.

\section{Does the Japanese government increase the primary surplus as the government debt grows?}

Will the Japanese government raise the tax rate drastically to stabilize the debt to GDP ratio? One way to answer this question is to examine how the fiscal policy responded to rising government debt in the past. If we observe the tendency for the government to reduce the primary deficit sufficiently in response to increasing government debt, for example, we can infer that the government may increase the tax rate to stabilize the debt eventually. Thus, this and the next section examine the Japanese government's responses to rising government debts in the last 30 years to see if we are likely to see drastic tax increases in the near future.

This section applies the approach proposed by Bohn (1998) that examines the response of the primary surplus to the debt. To illustrate the approach, let $x_{t}$ denote the ratio of primary surplus to GDP and suppose it is a linear function of the debt to GDP ratio in the (end of the) previous period:

$$
x_{t}=\alpha+\beta b_{t-1}+\rho x_{t-1}+\gamma z_{t}+u_{t}
$$

where $z$ is a vector of stationary variables that influences the primary surplus and $u$ is a Gaussian white noise with variance $\sigma^{2}$. In contrast to Bohn (1998), we allow the smoothed adjustment of primary surplus by including the AR(1) term.

In the following analysis, we use two variables for $z$. The first is GVAR, which is defined to be the temporary deviation from the trend level of government expenditure divided by GDP, namely $\mathrm{GVAR}_{t} \equiv\left(G_{t}-G_{t}^{*}\right) / Y_{t}$, where $G_{t}^{*}$ is the trend level of government expenditure calculated using the method proposed by Hodrick and Prescott (1997). The budget balance can worsen to finance a temporary surge in the government expenditure (such as a war) without jeopardizing the long-run sustainability. Thus, we expect to find the primary surplus respond negatively to this variable. The other stationary variable is GDP gap, which attempts to capture the fluctuations of the primary surplus coming from the automatic stabilizer function of the government budget. ${ }^{7}$ GDP gap is measured as the deviation of the Hodrick-Prescott trend. The primary surplus is likely to fall during economic downturns, so we expect a positive coefficient on this variable.

Note that the relation between the primary surplus and debt for a constant interest rate and a constant growth rate:

$$
b_{t}=(1+i-\eta) b_{t-1}-x_{t}
$$

\footnotetext{
${ }^{7}$ Bohn uses the unemployment rate to capture the business cycle fluctuations. Instead of GDP gap, he uses YVAR which is defined as $\mathrm{YVAR}_{t} \equiv\left(U_{t}-U^{m}\right)\left(G_{t}^{m} / Y_{t}\right)$, where $U_{t}$ is the unemployment rate, $U^{m}$ is the median unemployment rate for the sample. The choice of the variables follows Barro (1986).
} 
Substituting (9) into (10) obtains:

$$
b_{t}=(1+i-\eta-\beta) b_{t-1}-\rho x_{t-1}-\alpha-\gamma z_{t}-u_{t}
$$

Noting that $x_{t-1}=(1+i-\eta) b_{t-2}-b_{t-1}$ :

$$
b_{t}=(1+i-\eta-\beta+\rho) b_{t-1}-\rho(1+i-\eta) b_{t-2}-\alpha-\gamma z_{t}-u_{t}
$$

Thus, $b_{t}$ is expressed in the ADF regression form as:

$$
\left.\Delta b_{t}=\{(i-\eta)(1-\rho)-\beta)\right\} b_{t-1}+\rho(1+i-\eta) \Delta b_{t-1}-\alpha-\gamma z_{t}-u_{t}
$$

Thus, $b_{t}$ is stationary if $\beta \geqslant(i-\eta)(1-\rho)$. Thus, if the primary surplus responds substantially positively to an increase in the debt to GDP ratio (assuming that the interest rate is higher than the growth rate), the debt to GDP ratio tends to be stabilized in the long run.

Intuitively, the debt to GDP ratio grows over time at the rate of the interest rate minus the growth rate of GDP even if the primary balance is zero. In order for this ratio to be stabilized in the long run, the primary surplus must be at least as large. If the primary surplus follows the process specified in the Eq. (9), the long run level of the primary surplus to GDP ratio is given by $\beta /(1-\rho)$ times the debt to GDP ratio. Thus, if $\beta /(1-\rho)$ is greater than the interest rate minus the growth rate, the government debt is sustainable.

If we allow the response of the primary surplus to the debt to GDP ratio to depend on the level of debt to GDP ratio, so that $\beta=f\left(b_{t-1}\right)$, one can show that the debt process is sustainable if there exists $b^{*}$ such that $f(b) \geqslant(i-\eta)(1-\rho)$ for all $b>b^{*}$.

This paper expands the analysis of Bohn (1998) and its application to Japan by Doi and Ihori (2009) by considering the possibility that the debt dynamics changes over time. ${ }^{8}$ Instead of (9), we consider the specification:

$$
x_{t}=\alpha\left(S_{t}\right)+\beta\left(S_{t}\right) b_{t-1}+\rho\left(S_{t}\right) x_{t-1}+\gamma\left(S_{t}\right) z_{t}+\sigma\left(S_{t}\right) u_{t} .
$$

Here $S_{t}$ denotes the policy regime that follows a two-state Markov chain with transition probability matrix

$$
\left(\begin{array}{cc}
p_{11} & 1-p_{22} \\
1-p_{11} & p_{22}
\end{array}\right)
$$

whose $(i, j)$ element indicates the probability that the policy regime moves to Regime $i$ from Regime $j$.

A natural interpretation of "regimes" would be different fiscal policy stances by different administrations. But, we cannot have the number of regimes as large as the number of distinct administration to get statistically reliable estimates. This is especially so for Japan in the recent years when the typical administration lasted only for four quarters (or less). Thus, this paper restricts the number of potential regimes to be two.

Table 3 reports the estimation results by maximum likelihood estimation (MLE). The definition of the government sector here is the general government that includes the social security funds. ${ }^{9}$ We use the average of the adjusted net debt to GDP ratio for the previous four quarters as $b_{t-1}$. All other variables are seasonally adjusted using X12-ARIMA, if the seasonally adjusted series are not available. The sample period used for this estimation is 1981-2010Q1.

The table reports the results for two alternative specifications. Model 1 is a simple linear specification. Model 2 includes the quadratic term $\left(b_{t-1}-\bar{b}\right)^{2}$, where $\bar{b}$ is the sample mean of $b$. This is a simple way to introduce the dependence of the size of response $(\beta)$ on the debt to GDP ratio.

The estimation result of Model 1 suggests the existence of two regimes with somewhat different responses of the primary balance to increasing government debt. In Regime 1, the coefficient on the debt to GDP ratio is negative, suggesting an increase in the debt to GDP ratio leads to a reduction in the primary balance. The reduced primary balance (or the increase in the primary deficit) would

\footnotetext{
${ }^{8}$ We estimate a model without regime changes in the working paper version of this paper(Doi et al., 2011) and find the result very similar to that obtained by Doi and Ihori (2009): the estimated coefficient on the debt to GDP ratio is negative.

${ }^{9}$ In the working paper version of the paper (Doi et al., 2011), we report the result for just the central and local governments. We do not report the result here because it is qualitatively the same as the one for the general government.
} 
Table 3

Models with Markov switching for general government sector.

\begin{tabular}{|c|c|c|c|c|}
\hline & \multicolumn{2}{|l|}{ Model 1} & \multicolumn{2}{|l|}{ Model 2} \\
\hline & Regime 1 & Regime 2 & Regime 1 & Regime 2 \\
\hline Transition probability & $\begin{array}{l}0.9722 \\
(0.0193)\end{array}$ & $\begin{array}{l}0.9638 \\
(0.0193)\end{array}$ & $\begin{array}{l}0.9710 \\
(0.0233)\end{array}$ & $\begin{array}{l}0.9703 \\
(0.0227)\end{array}$ \\
\hline Constant & $\begin{array}{l}0.0015 \\
(0.0008)\end{array}$ & $\begin{array}{l}0.0012 \\
(0.0006)\end{array}$ & $\begin{array}{l}0.0012 \\
(0.0010)\end{array}$ & $\begin{array}{l}0.0017 \\
(0.0008)\end{array}$ \\
\hline$b_{t-1}$ & $\begin{array}{l}-0.0057 \\
(0.0012)\end{array}$ & $\begin{array}{l}0.0007 \\
(0.0010)\end{array}$ & $\begin{array}{l}-0.0057 \\
(0.0020)\end{array}$ & $\begin{array}{l}0.0007 \\
(0.0015)\end{array}$ \\
\hline$\left(b_{t-1}-\bar{b}\right)^{2}$ & & & $\begin{array}{l}-0.0027 \\
(0.0034)\end{array}$ & $\begin{array}{l}-0.0046 \\
(0.0068)\end{array}$ \\
\hline GVAR $_{\mathrm{t}}$ & $\begin{array}{l}-0.2803 \\
(0.0875)\end{array}$ & $\begin{array}{l}-0.2226 \\
(0.0842)\end{array}$ & $\begin{array}{l}-0.2423 \\
(0.0811)\end{array}$ & $\begin{array}{l}-0.2156 \\
(0.1000)\end{array}$ \\
\hline GDP gap & $\begin{array}{l}0.0013 \\
(0.0002)\end{array}$ & $\begin{array}{l}0.0001 \\
(0.0002)\end{array}$ & $\begin{array}{l}0.0011 \\
(0.0002)\end{array}$ & $\begin{array}{l}0.0000 \\
(0.0003)\end{array}$ \\
\hline$\rho$ & $\begin{array}{l}0.7057 \\
(0.0542)\end{array}$ & $\begin{array}{l}0.9378 \\
(0.0338)\end{array}$ & $\begin{array}{l}0.6347 \\
(0.0710)\end{array}$ & $\begin{array}{l}0.9094 \\
(0.0466)\end{array}$ \\
\hline$\sigma$ & $\begin{array}{l}0.0023 \\
(0.0002)\end{array}$ & $\begin{array}{l}0.0013 \\
(0.0001)\end{array}$ & $\begin{array}{l}0.0019 \\
(0.0002)\end{array}$ & $\begin{array}{l}0.0016 \\
(0.0002)\end{array}$ \\
\hline Log-likelihood & \multicolumn{2}{|c|}{563.9} & \multicolumn{2}{|c|}{564.1} \\
\hline MSC (with switching) & \multicolumn{2}{|c|}{-955.1} & \multicolumn{2}{|c|}{-942.8} \\
\hline MSC (without switching) & \multicolumn{2}{|c|}{-916.4} & \multicolumn{2}{|c|}{-917.7} \\
\hline
\end{tabular}

Notes: Estimated by the MLE assuming normality. The dependent variable is the primary balance divided by GDP. Numbers in the parentheses are standard errors. $b_{t-1}$ is the average of the debt to GDP ratios for the last four quarters, and $\bar{b}$ is its average over the sample period. GVAR is the deviation of the government expenditure from its trend divided by GDP. GDP gap is measured as the deviation from the Hodrick-Prescott trend. $\rho$ is the coefficient on the lagged dependent variable. MSC reports the value of Markov switching criteria proposed by Smith et al. (2006).

increase the growth rate of debt. The situation is clearly unsustainable. In this regime, the coefficient estimate on GDP gap is positive and statistically significant, suggesting strong counter-cyclical fluctuations of primary deficit. The probability that the economy stays in this regime in the next period is estimated to be about 0.97 . So the average duration of this regime is more than 8 years. ${ }^{10}$

In Regime 2, the coefficient estimate on the debt to GDP ratio is positive, suggesting that the dynamics could be sustainable. The coefficient estimate, however, is small and not statistically different from zero. In this regime, the coefficient on GDP gap is not significantly different from zero, suggesting little counter-cyclical fiscal policy. The probability that the economy stays in the regime is 0.96 , or the regime continues for about 6 years and a quarter on average.

We can use the value of Markov switching criterion (MSC) proposed by Smith et al. (2006) to compare regression models with and without Markov switching. The table shows that the MSC of Model 1 with Markov switching is smaller than that for the model without regime change. Thus, the MSC selects the model with regime changes over the model without regime changes.

Fig. 5 shows the smoothed probability of state being Regime 1 for Model 1 . We can see two occasions when the debt dynamics were clearly unsustainable (Regime 1). One is the period from the early 1990s to the early 2000s. This roughly corresponds to the period often referred to as the "lost decade." The primary deficit increased, while the debt to GDP ratio rose, making the debt dynamics clearly explosive. The other Regime 1 period is the late 2000s, when the budget deficit increased again as a response to the global economic crisis. In Regime 2, the point estimate of the coefficient on the debt to GDP ratio is positive but it is not significantly different from zero. Thus, the debt is not quite sustainable even in this regime, but the dynamics is less explosive than Regime 1 . The figure shows Japan was in Regime 2 in the late 1980s. The period is often considered to have been a period of fiscal consolidation, although the model suggests that the debt dynamics was explosive even then. The other

\footnotetext{
${ }^{10}$ The average duration of Regime is given by $1 /\left(1-\rho_{i i}\right)$. See Kim and Nelson (1999, p. 72$)$.
} 


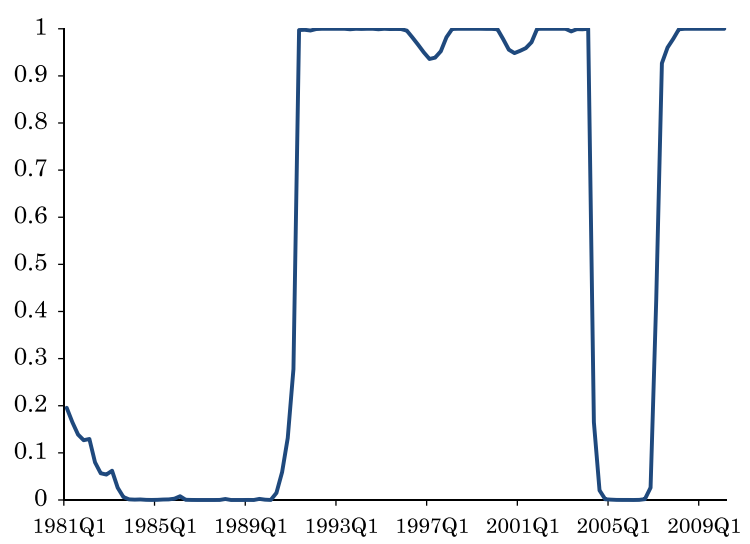

Fig. 5. Smoothed probability of Regime 1 for the Model 1 for general government sector.

Regime 2 period emerged in the mid 2000s, which corresponds to the fiscal consolidation attempt under the Koizumi government.

Model 2 includes the quadratic term in the specification. Again Regime 1 is a clearly unsustainable regime: the budget balance falls as the debt to GDP ratio increases for all the possible values of the debt to GDP ratio. The probability that the economy stays in this regime is estimated to be 0.97 . In Regime 2, the coefficient on the debt to GDP ratio is positive, so the dynamics can be sustainable. The positive coefficient estimate on the linear term, however, is again small and not statistically different from zero.

The MSC values suggest that Model 1 is preferred over Model 2. The model suggests that the primary surplus did not respond positively to increasing debt to GDP ratio in either regime. Thus, a fiscal policy change that is required to restore fiscal sustainability for the general government sector will have to be an unprecedented change (at least in the last 30 years). ${ }^{11}$

In summary, the analysis in this section points to serious problems for the Japan's government debt. For both the general government sector and the central/local government only, the fiscal policy is found to be unsustainable, even when we allow for the possibility of regime changes.

Ito et al. (this issue) estimate a similar model of the debt dynamics with possible regime changes. Looking at a longer sample period (1885-2004), they find the Japanese fiscal policy is overall stable. In the periods 1885-1925 and 1950-1970, the primary surplus responded substantially positively to an increase in the debt. Our result, which comes from the analysis of the sample after 1980, is not inconsistent with their finding, because our sample period does not contain those years when they find the fiscal policy was sustainable. We interpret their result to imply that the Japanese fiscal policy can be sustainable if Japan can go back to the policy regime in 1885-1925 (roughly under the gold standard) and in 1950-1970 (effective balanced budget legislation) with high probability. Without such drastic changes, the fiscal policy is unsustainable.

\section{Fiscal sustainability and monetary policy}

The analysis in Section 5 looked at the response of the primary surplus to the debt. Thus, it was not clear whether the tax revenue or the government expenditure changes responding to the changes in the level of government debt. This section focuses on the adjustment of the tax revenue side and investigates if the tax revenue has shown the tendency to increase as the debt increases given the government expenditure.

\footnotetext{
${ }^{11}$ When we use the unemployment rate based measure instead of GDP gap to proxy for the business cycle, the model with the quadratic term with Markov switching becomes the most preferred model by the MSC. In Regime 2, the policy becomes sustainable for low levels of debt to GDP ratio. Such sustainable situation, however, did not actually happened in the last 30 years because the debt to GDP ratio was already high when the economy was in Regime 2 with high probability.
} 
Table 4

Estimation results of the fiscal policy function for general government sector.

\begin{tabular}{lll}
\hline & Regime 1 & Regime 2 \\
\hline Transition probability & 0.9374 & 0.9771 \\
& $(0.0404)$ & $(0.0165)$ \\
Constant & 0.0623 & 0.0812 \\
& $(0.0070)$ & $(0.0040)$ \\
Lagged (debt/GDP) & -0.0268 & -0.0003 \\
GDP gap & $(0.0035)$ & $(0.0009)$ \\
& -0.0004 & 0.0001 \\
Government expenditure/GDP & $(0.0003)$ & $(0.0002)$ \\
& 0.6425 & 0.3196 \\
$\sigma$ & $(0.0762)$ & $(0.0353)$ \\
& 0.0020 & 0.0020 \\
Log-likelihood & $(0.0003)$ & $(0.0002)$ \\
MSC (with switching) & 549.4 & \\
MSC (without switching) & -948.3 & \\
\hline
\end{tabular}

Notes: Estimated by the MLE assuming normality. The dependent variable is the tax revenue divided by GDP. Numbers in the parentheses are standard errors. The lagged debt to GDP ratio is the average of the debt to GDP ratios for the previous four quarters. GDP gap is measured as the deviation from the Hodrick-Prescott trend. MSC reports the value of Markov switching criteria proposed by Smith et al. (2006).

We examine how the tax revenue responds to the debt to GDP ratio by estimating a Markov switching model used by Davig and Leeper (2007). They specify the fiscal policy function in terms of the tax revenue to GDP ratio as a function of the debt to GDP ratio, output gap, and government purchases:

$$
\tau_{t}=\alpha\left(S_{t}\right)+\beta\left(S_{t}\right) b_{t-1}+\gamma_{y}\left(S_{t}\right) g a p_{t}+\gamma_{g}\left(S_{t}\right) g_{t}+\sigma\left(S_{t}\right) u_{t}
$$

where gap $_{t}$ stands for the output gap. We calculate the output gap as the deviation of GDP from its Hodrick-Prescott trend.

Table 4 shows the estimation results of the fiscal policy function (15) for the general government sector by the MLE assuming normality. ${ }^{12}$ Two regimes are identified. In Regime 1 , the coefficient estimate on the debt to GDP ratio is negative, suggesting the tax revenue falls when the debt to GDP ratio increases. The smoothed probability of Regime 1 is shown in Fig. 6. According to the terminology originally developed by Leeper (1991), an "active" policy is not constrained by the level of government debt. The fiscal policy in Regime 1 is "active" in this sense. In contrast, a "passive" policy responds prudently to shocks to the government debt. For the US data, Davig and Leeper (2007) find the fiscal policy alternates between the "active" phase and the "passive" phase that is characterized by a positive coefficient on the debt to GDP ratio. For the general government sector of Japan, we find the coefficient on the debt to GDP ratio in Regime 2 to be zero.

Thus, regardless the state, the tax revenue fails to increase when the debt to GDP ratio rises. In both regimes, the tax revenue increases when the government expenditure increases but by much less than one-to-one. The fiscal dynamics for Japan does not show the tax adjustment to make the fiscal policy sustainable.

An active fiscal policy is not necessarily unsustainable. As Davig and Leeper (2011) and others show, an active fiscal policy can be sustainable if the monetary authority acts "passively" and allows the price level to adjust eventually to make the value of the government bonds outstanding equal to the present discount value of future expected primary surpluses. Because the Japanese fiscal policy has

\footnotetext{
12 The working paper version (Doi et al., 2011) estimate the fiscal policy function for the central and local governments sector only and obtains the qualitatively similar result.
} 


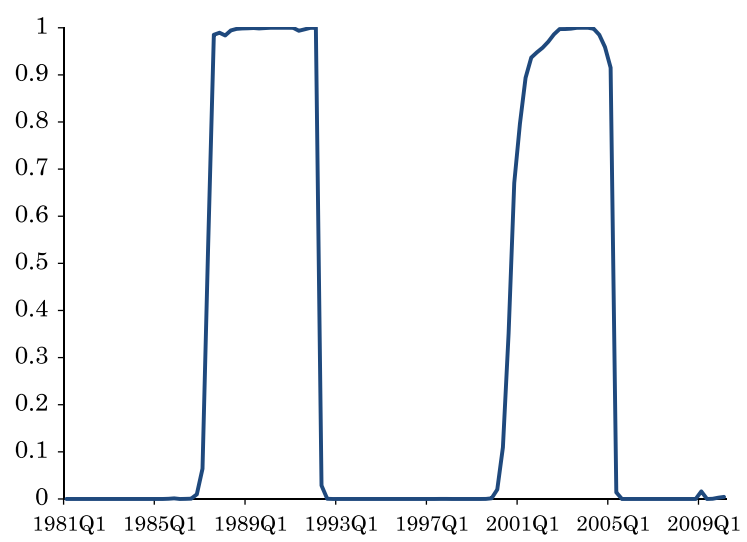

Fig. 6. Smoothed probability of Regime 1 for the fiscal policy function of general government sector.

looked active in the last 30 years both at the level of the general government sector and at the level of the central/local governments, it is important to check how the monetary policy has been conducted. ${ }^{13}$

To check this, we estimate the following monetary policy function, which is potentially state dependent.

$$
\text { call }_{t}=\alpha_{M}\left(S_{t}^{M}\right)+\beta_{M}\left(S_{t}^{M}\right) \pi_{t}+\delta_{y}\left(S_{t}^{M}\right) \operatorname{gap}_{t}+\delta_{e}\left(S_{t}^{M}\right) e x_{t}+\sigma\left(S_{t}^{M}\right) v_{t},
$$

where call $_{t}$ is the quarterly average overnight call rate (nominal), $\pi_{t}$ is the inflation rate measured as the rate of change of GDP deflator from four quarters ago, gap $p_{t}$ is the real GDP gap and $e x_{t}$ is the deviation of the real effective exchange rate from its trend. ${ }^{14}$ The trend GDP and the trend real exchange rate are the HP trend of each series. $S_{t}^{\mathrm{M}}$ is the monetary policy regime that evolves according to a Markov chain.

Table 5 reports the estimation results. ${ }^{15}$ Column 1 reports the estimated coefficients from the model without regime switches. The estimated coefficient on the inflation rate is much greater than one, suggesting an active monetary policy to maintain a targeted inflation rate. When the actual inflation rate goes up above the target rate, the central bank raises the interest rate by more than one to one, raising the real interest rate. Such monetary policy eventually brings the inflation rate back to the target level. Thus, the model that ignores the possibility of regime changes for the monetary policy suggest that the monetary policy in Japan has been "active" in the sense that the central bank reacted strongly to deviations of the inflation rate from its target level. The combination of active fiscal policy and active monetary policy is unsustainable. This combination cannot continue forever. Eventually, either the fiscal authority or the monetary authority is forced to be inactive and accommodate the other.

The coefficients on the variables other than the inflation rate are not precisely estimated in the model without regimes changes, although the point estimates have the expected signs. When the output falls below the trend (gap variable is negative), the monetary policy becomes more expansionary

\footnotetext{
13 The literature on "active" versus "passive" policies so far has not considered the implications of the zero bound for the nominal interest rate, which could be important for the Japanese case. Takeda (2002) was probably the first paper to discuss the implications of "active" and "passive" fiscal policies using the data from Japan. Using the data from an earlier period (1970-1990) and slightly different specifications, he finds both fiscal and monetary policies are "passive." If both policies are passive, the price level is indeterminate. He interprets this to imply the passiveness of the policies allow the deflation in Japan and suggests a (temporarily) active fiscal policy to be a solution to end the deflation.

14 The data on the call rate and the real effective exchange rate come from the Bank of Japan web site (http://www.boj.or.jp). The data on GDP and GDP deflator come from the SNA account (http://www.esri.cao.go.jp/en/sna/menu.html).

${ }^{15}$ In these estimations, we do not explicitly take the zero nominal bound for the nominal interest rate (the dependent variable of the regression) into account. We also estimated a Tobit model for two sub periods suggested by the model with regime changes (before 1995 and after 1995). The coefficient estimates are similar to those from the Markov switching model.
} 
Table 5

Estimation results for monetary policy function.

\begin{tabular}{llll}
\hline & Model without switching & \multicolumn{2}{l}{ Model with switching } \\
\cline { 3 - 4 } & & Regime 1 & Regime 2 \\
\hline Transition probability & & 0.991 & 0.991 \\
& & $(0.011)$ & $(0.012)$ \\
Constant & 2.500 & 4.140 & 0.333 \\
\multirow{2}{*}{$\pi_{t}$} & $(0.120)$ & $(0.234)$ & $(0.035)$ \\
gap & 1.681 & 0.875 & 0.137 \\
& $(0.079)$ & $(0.139)$ & $(0.030)$ \\
ex & 0.033 & 0.192 & 0.056 \\
& $(0.095)$ & $(0.134)$ & $(0.013)$ \\
$\sigma$ & -0.017 & -0.090 & -0.008 \\
& $(0.018)$ & $(0.020)$ & $(0.003)$ \\
Log-likelihood & 1.272 & 0.975 & 0.123 \\
MSC & $(0.084)$ & $(0.084)$ & $(0.011)$ \\
\hline
\end{tabular}

Notes: Estimated by the MLE assuming the error term are normally distributed with mean 0 and variance $\sigma^{2}$. The dependent variable is the average overnight call rate. Numbers in the parentheses are standard errors. gap is the GDP gap, which is measured as the deviation from the Hodrick-Prescott trend. ex is the deviation of the real effective exchange rate from its Hodrick-Prescott trend. MSC reports the value of Markov switching criteria proposed by Smith et al. (2006).

(lower interest rate). When the real exchange rate appreciate above the trend (ex variable is positive), the monetary policy becomes expansionary.

The result for active monetary policy disappears when we estimate a model with regime switches. The last two columns of Table 5 report the result for the Markov switching model. The MSC suggests that the model with regime switches is much more preferred to the one without. The coefficient on the inflation rate is less than one in both regimes, suggesting the monetary policy is inactive. Regime 1 is relatively more active but the coefficient estimate is still less than one. The response to the output gap in Regime 1 is large but not precisely estimated. The response to the exchange rate is significantly different from zero.

Regime 2 shows the smaller response of the interest rate to all the variables, but each coefficient estimate is statistically significantly different from zero. Regime 2 also shows low volatility of the interest rate.

Fig. 7 shows the smoothed probability of Regime 1. Regime 1 lasted for the first 15 years of the sample. From the third quarter of 1995 (note this is when the Bank of Japan lowered the target rate to 0.5\%)

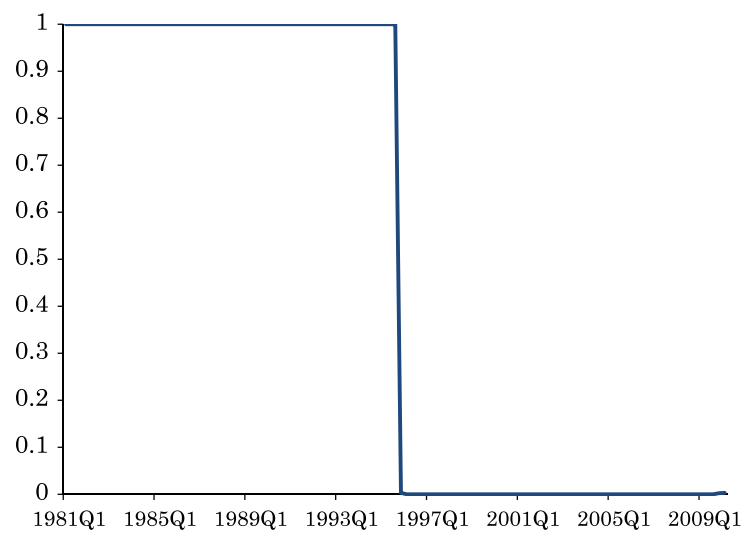

Fig. 7. Smoothed probability for Regime 1 for the monetary policy equation. 
to the fourth quarter of 1995 , the monetary policy quickly moved to Regime 2 , which has been continuing for the next 15 years.

Given this result, we suspect that the result for active monetary policy in the model without regime switches came mostly from the comparison between the period before 1995 (high inflation rate and high interest rate) and the period after 1995 (low inflation rate and low interest rate). Within each regime, the interest rate never responded to the inflation rate by more than one for one.

The analysis of this section finds fluctuations of regimes of fiscal policy and monetary policy. Unlike the results for the US found by Davig and Leeper (2007), we do not find the policies fluctuate between active and inactive regimes. For the fiscal policy, both regimes are active. For the monetary policy, both regimes are inactive. Thus, this section's analysis suggests that the active fiscal policy has been supported by inactive monetary policy in Japan for the last 30 years. If this pattern persists, the most likely scenario for the future reconciliation of the mounting government debt may be the reduction of the value of government debt through inflation under accommodative monetary policy, however unlikely it seems in the current deflationary environment.

\section{Conclusions}

In this paper, we have examined the fiscal sustainability of Japan using three alternative but complementary approaches and for two alternative definitions of the government sector. All the results point to the same conclusion: the Japanese government debt poses serious challenges. To stabilize the debt to GDP ratio, Japan needs to implement a tax rate hike with an extraordinary magnitude. Such tax increase to make the fiscal policy sustainable would represent a drastic departure from the Japanese fiscal policy in the last 30 years. The fiscal policy in Japan is found to be unsustainable even when we allow the possibility of regime changes. If the government fails to reduce the primary deficit by increasing the taxes and reducing the expenditures and transfer payments, Japan would be forced to reduce the value of government debt through either inflation or outright default.

\section{Acknowledgments}

We thank Shin-ichi Fukuda, Yasushi Iwamoto, Hugh Patrick and two anonymous referees for valuable suggestions. We also thank participants of the 23rd NBER-TCER-CEPR Conference at University of Tokyo and the 12th annual conference of the Association for Public Economic Theory at Indiana University and seminars at University of California, San Diego and Australian National University for helpful comments. Doi has received a financial support from the Grant-in-Aid for Specially Promoted Research from Japan's Ministry of Education, Culture, Sports, Science and Technology: "Economic Analysis of Intergenerational Issues: Searching for Further Development" (Grant Number 22000001). All remaining errors are our own.

\section{References}

Barro, Robert, 1986. US deficits since world war I. Scand. J. Econ. 88, 195-222.

Blanchard, O., Chouraqui, J.-C., Hagemann, R.P., Sartor, N., 1990. The sustainability of fiscal policy: new answers and to an old question. OECD Econ. Stud. 15, 7-36.

Bohn, Henning, 1998. The behavior of US public debt and deficits. Quart. J. Econ. 113, 949-963.

Broda, Christian, Weinstein, David E., 2005. Happy news from the dismal science: reassessing Japanese fiscal policy and sustainability. In: Ito, Takatoshi, Patrick, Hugh, Weinstein, David E. (Eds.), Reviving Japan’s Economy. MIT Press, Cambridge, MA, pp. 40-78.

Davig, Troy, Leeper, Eric M., 2007. Fluctuating Macro Policies and the Fiscal Theory. NBER Macroeconomics Annual, vol. 21, pp. 247-298.

Davig, Troy, Leeper, Eric M., 2011. Monetary-fiscal policy interactions and fiscal stimulus. Eur. Econ. Rev. 55 (2), $211-227$.

Doi, Takero, 2008. Simulation analysis of policies to ensure Japan's fiscal sustainability. Mita J. Econ. 100 (4), 131-160.

Doi, Takero, 2009. Zaisei Shutsudo no Utage no ato ni. In: Ito, Takatoshi, Yashiro, Naohiro (Eds.), Nihon Keizai no Kassei-ka (Revitalizing Japan's Economy). Nihon Keizai Shimbun-sha, Tokyo, Japan, pp. 155-189.

Doi, Takero, Ihori, Toshihiro, 2009. The Public Sector in Japan: Past Developments and Future Prospects. Edward Elgar, Cheltenham, UK.

Doi, Takero, Hoshi, Takeo, Okimoto, Tatsuyoshi, 2011. Japanese Government Debt and Sustainability of Fiscal Policy. NBER Working Paper. 
Hodrick, Robert, Prescott, Edward C., 1997. Postwar US business cycles: an empirical investigation. J. Money, Credit, Banking 29 (1), 1-16.

Ito, Arata, Watanabe, Tsutomu, Yabu, Tomoyoshi, 2011. Fiscal Policy Switching in Japan, the US, and the UK. J. Japanese Int. Economies 25, 380-413.

Kim, Chang-Jin, Nelson, Charles, 1999. State-space Models with Regime Switching: Classical and Gibbs-sampling Approaches with Applications. MIT Press, Cambridge, MA.

Leeper, Eric M., 1991. Equilibria under 'active' and 'passive' monetary and fiscal policies. J. Monet. Econ. 27, 129-147.

Smith, Aaron, Naik, Prasad A., Tsai, Chih-Ling, 2006. Markov-switching model selection using Kullback-Leibler divergence. J. Econometrics 134, 553-577.

Takeda, Yosuke, 2002. Defure ka ni okeru zaisei seisaku ruru wo motomete (Searching for the fiscal policy rule in a deflationary economy), (The Ministry of Finance) financial. Review 64, 140-179. 